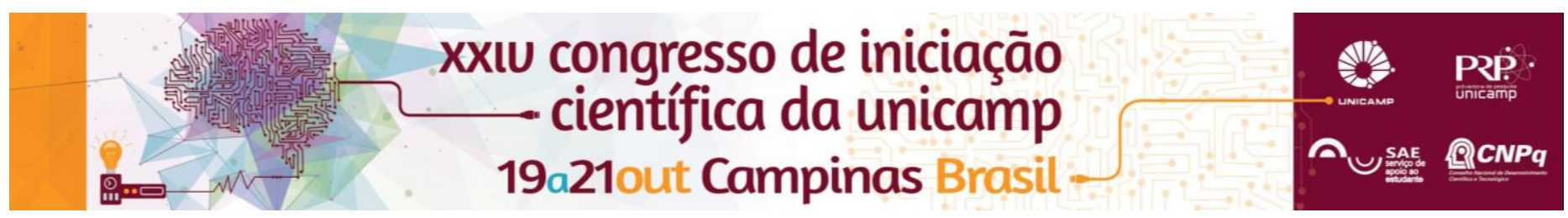

\title{
Programa de Formação Interdisciplinar Superior - ProFIS e o acesso ao Ensino Superior
}

\author{
Joice de Oliveira Silva*, Aquiles Coelho Silva.
}

\section{Resumo}

O Ensino Superior se encontra como o nível de ensino que mais se expande, proporcionalmente, dentro do sistema educacional brasileiro. É neste cenário que as ações afirmativas ganham destaque, propondo uma reflexão sobre o acesso às universidades no Brasil. O ProFIS se encontra hoje em seu sexto ano, assim pretende-se aqui fazer uma análise comparativa do perfil dos alunos ingressantes em 2011 e em 2016.

\section{Palavras-chave:}

ProFIS, Ações Afirmativas, Ensino Superior.

\section{Introdução}

A partir da década de 90 observa-se um grande crescimento do sistema educacional no Brasil, através de políticas que buscam a universalização da educação básica, tendo como marcos a LDB, de 1996 e o PNE de 2001. É a partir deste cenário que se desenha um período de expansão do ensino superior, principalmente através da iniciativa privada, mas também com um aumento significativo das instituições públicas. Ainda que tenha ocorrido esta ampliação, 0 acesso às universidades é desigual entre os setores da sociedade. Constata-se que pobres e negros enfrentam maiores barreiras para concluir, ou mesmo ingressar no ensino superior. Pensando em formas de democratizar o acesso ao ensino superior as ações afirmativas ganham destaque na política nacional, com seu maior marco em 2012, com a instituição da política de Cotas para todas as universidades federais.

No Estado de São Paulo as universidades estaduais também passam a repensar o acesso dos seus alunos através de políticas afirmativas. A UNICAMP apresenta uma inovação no que diz respeito a métodos de inclusão através do ProFIS, um curso sequencial, de formação interdisciplinar, com duração de quatro semestres. Ele é dirigido aos estudantes que concluíram o ensino médio provenientes das escolas públicas do município de Campinas. Após concluir o curso sequencial, todos os alunos ingressam diretamente nos cursos de graduação da UNICAMP, sem necessidade de passar pelo vestibular. $O$ acesso é dado pelas vagas oferecidas em cada instituto - para o ProFIS - e pelo ranqueamento dos alunos, de acordo com o seu desempenho no curso sequencial. Assim, o curso de graduação é elegido prioritariamente pelo aluno que tiver o coeficiente de rendimento mais alto.

\section{Resultados e Discussão}

Os dados que serão tratados foram coletados através de um questionário de matricula aplicado no dia de ingresso pela Avaliação Continuada do ProFIS, constituído por pesquisadores do NEPP.

Durante a avaliação percebemos que não houve mudanças no perfil dos ingressantes relativas ao sexo ou a idade. No que diz respeito ao sexo, permanece uma pequena seletividade feminina, com $56 \%$ de mulheres ingressantes em 2011 e 2016. Quanto a idade, a média se manteve em 18,3 anos, tal qual a mediana, que é de 18 anos.

Há uma mudança na forma a qual os estudantes tomam conhecimento sobre o projeto. Em ambos os anos mais da metade dos matriculados no ProFIS tomaram conhecimento sobre o programa na escola através do diretor ou professor. Em 2011 a segunda forma de conhecimento sobre o curso foi através de visitas de professores e/ou alunos da UNICAMP nas escolas públicas do Ensino Médio. Em 2016 há uma inversão, pois os amigos passam a ser a segunda maior fonte de informação sobre o programa. Esta mudança parece indicar uma popularização do projeto, que passa a ter cada vez mais inscritos.

$\mathrm{O}$ dado que mais nos chamou atenção diz respeito à participação dos ingressantes em outros processos seletivos além do ProFIS. Enquanto em 2011 67\% dos ingressantes participaram de algum outro processo seletivo, em 2016 esta porcentagem subiu para $81 \%$. Destes, em 2011 25\% tiveram alguma aprovação em outra instituição de ensino. Em 2016 44\% dos alunos obtiveram o mesmo resultado.

\section{Conclusões}

Concluímos que o programa se expandiu e popularizouse no período, atraindo cada vez mais jovens. A idade se mantém constante nos anos selecionados devido ao método de ingresso ao ProFIS, que se dirige aos alunos do terceiro ano do ensino médio. $O$ gênero dos estudantes aponta para uma leve predominância feminina, contrária ao perfil geral dos estudantes dos cursos de graduação regulares na UNICAMP. Entretanto, mais estudos são necessários para melhor entender o processo em curso.

\section{Agradecimentos}

Agradecemos à Ana Maria Carneiro, Stella Maria Barbera da Silva Telles e à todo o corpo de pesquisadores do Núcleo de Estudos de Políticas Públicas.

\footnotetext{
1 SCHWARTZMAN, S. (2015). Massificação, equidade e qualidade: Os desafios da educação Superior no Brasil - Análise do Período 2009-2013. Disponível em https://archive.org/details/universia_port_201501
}

2 ANDRADE, C.Y. (2012) Acesso ao ensino superior no Brasil: equidade e desigualdade social. Revista Ensino Superior Unicamp, n.6, Julho-AgostoSetembro 2012. Unicamp.

3 GOMES, F. A. M.; SILVA, A. M. A. C. Programa de Formação Interdisciplinar educação superior. p. 698-719, 2011. 